noither Lord Stonham nor the Lord Chancellor gave the assuranco that it would receive favourable consideration for which Lord Molson hoped.

\section{Desalination of Sea-water}

LoRD Molson also supported some observations made by Lord Weir on the desalination of soa-water and expressed the hope that the now Department, to which responsibility for water supply and conservation had been specifically transferred, would direct special attention to the neod for increased economy in the use of water and give expert consideration to the Morecambe Bay barrage project. Lord Weir dealt with desalination in somo detail, directing attention to the roport published this year by the United Nations. Moreover, he stressed the significance of the multi-flush distillant developed independently and almost simultaneously in 1956 by two British engineers, Dr. R. S. Silver and Dr. A. Frankel, giving $11 \mathrm{lb}$. of distillate from $1 \mathrm{lb}$. of stoam instead of the previous $4 \mathrm{lb}$., and halving the capital costs. Between 1959 and 1964 the two British firms involved had securod orders for forty installations, or somo 70 per cent of the available market. While welcoming the grant made by the Department of Scientific and Industrial Rosoarch to the Wator Research Association to investigate the true incremental costs of additions to conventional wator supply, he hoped that besides attention boing directed to the invisible factors, the possibilities of distillation of sea-wator, utilizing nuclear reactors as a source of heat, would not be over. looked. $\mathrm{H}_{\theta}$ also welcomed the establishment by the Department of Scientific and Industrial Research of an advisory committeo and its financing of research into desalination economics. Lord Bessborough, speaking on the following day, supported Lord Weir, and added that the Amoricans greatly valued Britain's co-operation in this field and wished to seo it extended.

\section{Inland Waterways}

ON November 11, Viscount St. Davids pressed the claims of the waterways to be considered in a co-ordinated transport systom. Their working loss had already been reduced from more than $£ 1$ million to just more than $£ 500,000$. Including capital and interest the working loss had been reduced by 26 per cent. With a further measure now being prepared by the British Waterways Board, he thought that the waterways would pay thoir way, but he also stressed the importance of the use of the waterways for purposes other than transport. Britain was in great need of major waterways which could carry cargoes of substantial size where specd was not of the first importance. Lord Lindgren, Parliamentary Secretary to the Ministry of Transport, assured Lord St. Davids of his interest in the waterways and that he had taken careful note of what he had said. He hoped that the Board's further review would enable the Government to docide on its policy and to start preparing the necessary legis lation. On transport generally, the Governmont's policy was towards an intograted system covering road, rail, inland waterways, air and coastal shipping, using the most suitable vehicle for the journey to be made and the traffic to be carried, and geared to meet the economic and social needs of Britain.

\section{Iron and Steel Industry}

During his speoch in the debate on the iron and steol industry in the House of Commons on November 9, the Minister of Powor, Mr. F. Lee, said that since the industry's research effort had bcen eriticized in a special report from the Iron and Steel Board in 1963 (sce Nature, 201, 853; 1964) research expenditure seemed to havo increased appreciably in tho industry as a whole. Four major companies wero planning substantial additional facilities for laboratory research, and the British Iron and Steel Resoarch Association was to construct a new iron-making laboratory. The Government, however, knew of no plans for inereasing the resources devoted to long-range research or for providing adequate facilities for large-scale plant work within tho industry. On this point Mr. J. H. Osborn said, later in the debate, that the expenditure of $£ 9.3$ million on research in 1963 almost reached the figure recom. mended by the Board, and that the manpower devoted to research increased by 25 per cent last yoar.

\section{Industrial and Technological Manpower}

IN his Budget statement in the House of Commons on November 11, the Chancellor of the Exchequer, Mr. J. Callaghan, said that large and important parts of Britain's industrial and technological manpower and capacity were locked up in production and research for the Government. It would be an urgent task to see how far this pattern could be modified in the national interest to release resources for more productive purposes and for expanding exports. Of the $£ 2,000$ millions spent on defence, more than $£ 350$ million was spent overseas, and it was the Government's intontion to relate commitments to resources and ensure that the Armed Forces could discharge their tasks with greater effectiveness and economy. Government expenditure in the civil field would also be examined and it was intended to ask a task group of senior officials, including scientific and economic advisers, to sort out their projects and appraise their economic priority. The Chief Secretary to the Treasury would review the remaining fields of civil expenditure, and would consider whether the established priorities were right or whether men and plant could be released for other work. The basic objoctive would be to revoal any areas where expenditure was not yielding full value in social and economic terms. However, it was also recognized that there were fields in which increased Government oxpenditure could assist modernization and accelerate technical progress.

\section{British House Journals Competition}

House journals (alias staff magazines, works news. papers, etc.) are valuable vehicles of two-way communication between people in the board room and the shop floor or counter. They range from the office-duplicated bulletin to the glossy magazine that vies with the best on the bookstalls. One of the principal objects of the British Association of Industrial Editors, the professional body for house journal editors, is improvement in the standard of industry's private press. To this end, an annual national open competition is held, which is judgod by a panel of experts nominated by the Institute of Journalists, the National Union of Journalists, the British Federation of Master Printers and the Society of Industrial Artists. Among the awards are four major trophies: (1) the best journal distributed to employees, presented by the Monotype Corporation, Ltd.; (2) the best journal for external readership, presented by the Kings Town Engraving Co.; (3) the best-designed house journal, presented by the De La Rue Co., Ltd.; (4) the best newspaper, presented by Lord Crook. In addition, the Shell-Mex and B.P. Trophy is awarded for the best house story of the year. The next competition closes on January 15 , 1965. Entry forms can bo obtained from the competition secretary, Mr. John Eve, c/o Standard 'L'elephones and Cables, Ltd., Thorese Houso, Glasshouse Yard, Aldersgato Street, London, E.C.l.

\section{The Grassland Research Institute}

Much of the work of the Grassland Research Institute, Hurley, is concerned with the interactions of soil, pastures and grazing animals in relation to other parts of the environmont (Experiments in Progress, No. 16: Annual Report for 1962-63. Pp. $100+4$ plates. Hurley, near Maidenhead: The Grassland Research Institute, 1964. 10s.). The research programme is planned to maintain 